\title{
Irregular cosmetic withdrawal from Brazilian market: descriptive analysis from
}

\section{9 to 2020}

Cosméticos irregulares recolhidos do mercado brasileiro: análise descritiva de 2009 a 2020

Cosméticos irregulares recogidos del mercado brasileño: análisis descriptivo de 2009 a 2020

Túlio Eduardo Soares Costa ORCID: https://orcid.org/0000-0001-9991-9735 Universidade Federal de São João del-Rei, Brazil

E-mail: tulioeduardosc@gmail.com

Marina Goulart da Silva

ORCID: https://orcid.org/0000-0002-1927-8630 Universidade Federal de São João del-Rei, Brazil E-mail: marina@ufsj.edu.br

Amanda Maria de Paiva

ORCID: https://orcid.org/0000-0002-1737-0249 Universidade Federal de São João del-Rei, Brazil E-mail: amandampaiva@outlook.com

Paula Resende Daher Chaves

ORCID: https://orcid.org/0000-0003-3611-1063 Universidade Federal de São João del-Rei, Brazil E-mail: pauladaher.farma@gmail.com

Douglas Vieira Thomaz

ORCID: https://orcid.org/0000-0003-0000-3466 Universidade Federal de Goiás, Brazil E-mail: douglasvthomaz@gmail.com

Renê Oliveira do Couto

ORCID: https://orcid.org/0000-0002-3748-3427 Universidade Federal de São João del-Rei, Brazil E-mail: rocouto@ufsj.edu.br

\begin{abstract}
Cosmetic products are essential items in everyday life and directly related to a good quality of life. This branch has been steadily growing in Brazilian market even in the midst of the economic crisis. Thence, it is the role of the Brazilian National Health Surveillance Agency (Anvisa) to establish standards, guidelines and surveillance actions in relation to these products. In this work, we therefore aimed to perform the descriptive analysis of cosmetics which were considered by Anvisa as irregular products between 2009 and 2020. Results were evaluated according to the following attributes: companies; motives; products; and inspection actions. The analysis encompassed a total of 872 notifications, which showcased that the majority of companies with irregular products are located in the Southeast region (64\%), mainly in São Paulo. There was an expressive degree of recurrence of the notified companies, which together were responsible for $40 \%$ of the total withdrawals. The most frequent motivations for the application of sanctions were: the absence of product registration/notification (35.3\%); quality deviations (25.9\%); and the lack of a business license $(20.0 \%)$. The most commonly withdrawn products were those for hair use, which may indicate strong relation with the use in beauty salons. In addition, there was a large increase in the irregularity of antiseptic gels in 2020. The number of revocations was low, what suggests lack of adequate quality management in the notified companies. In conclusion, Anvisa has fulfilled its institutional objective of standardization, thereby establishing and enforcing adequate product safety countrywide.
\end{abstract}

Keywords: Cosmetics; Quality control; Health surveillance; Recalls; Withdrawals.

\section{Resumo}

Produtos cosméticos são itens essenciais no dia a dia e diretamente relacionados a uma boa qualidade de vida. Esse ramo da indústria brasileira tem crescido constantemente mesmo em meio à crise econômica. É papel da Agência Nacional de Vigilância Sanitária (Anvisa), por meio de suas atribuições, estabelecer normas, diretrizes e ações de vigilância com relação a esses produtos. Neste trabalho, realizamos a análise descritiva de cosméticos tido como irregulares no Brasil entre 2009 e 2020, por meio do website da Anvisa na subseção de "produtos irregulares". Foram obtidos resultados de variáveis denominadas: empresas, motivos, produtos e ações fiscalizadoras. Os resultados foram apresentados como frequências absoluta ou relativa. A análise do total de 872 notificações mostrou que a maioria das empresas com produtos irregulares são localizadas na região Sudeste (64\%), principalmente em São Paulo. 
Evidenciou-se um expressivo grau de reincidência das empresas notificadas, que juntas foram responsáveis por $40 \%$ do total de recolhimentos. As motivações mais frequentes para aplicação de sanções foram a ausência de registro/notificação do produto $(35,3 \%)$, desvios de qualidade $(25,9 \%)$ e a falta de alvará de funcionamento $(20,0 \%)$. Os produtos mais comumente retirados do mercado foram os de uso capilar, o que pode indicar forte relação com o uso em salões de beleza. Além disso foi evidenciado um grande crescimento de irregularidades em géis antissépticos em 2020. O número de revogações foi baixo, o que mostra fragilidade na política de qualidade das empresas notificadas. Portanto, a Anvisa tem cumprido com seu objetivo institucional de normatização, estabelecendo ferramentas que propiciam uma produção de qualidade quando seguidas.

Palavras-chave: Cosméticos; Controle de qualidade; Vigilância sanitária; Recall; Retirada.

\section{Resumen}

Los productos cosméticos son elementos imprescindibles en el día a día y directamente relacionados con una buena calidad de vida. Esta rama de la industria brasileña ha crecido de manera constante incluso en medio de la crisis económica. Es función de la Agencia Nacional de Vigilancia Sanitaria (Anvisa), a través de sus atribuciones, establecer normas, lineamientos y acciones de vigilancia en relación a estos productos. En este trabajo, realizamos el análisis descriptivo de los cosméticos considerados irregulares en Brasil entre 2009 y 2020, a través del sitio web de Anvisa en la subsección de "productos irregulares". Los resultados se obtuvieron de las variables denominadas: empresas, motivos, productos y acciones de inspección. Los resultados se presentaron como frecuencias absolutas o relativas. El análisis del total de 872 notificaciones mostró que la mayoría de las empresas con productos irregulares están ubicadas en la región Sudeste (64\%), principalmente en São Paulo. Hubo un expresivo grado de reincidencia de las empresas notificadas, que en conjunto fueron responsables del $40 \%$ de las recaudaciones totales. Las motivaciones más frecuentes para aplicar sanciones fueron la ausencia de registro / notificación de producto (35,3\%), desviaciones de calidad $(25,9 \%)$ y la falta de licencia comercial $(20,0 \%)$. Los productos más comúnmente retirados del mercado fueron los de uso capilar, lo que puede indicar una fuerte relación con el uso en salones de belleza. Además, hubo un gran aumento de irregularidades en los geles antisépticos en 2020. El número de retiradas fue bajo, lo que muestra debilidad en la política de calidad de las empresas notificadas. Por lo tanto, Anvisa ha cumplido con su objetivo institucional de estandarización, estableciendo herramientas que brindan una producción de calidad cuando se sigue.

Palabras clave: Cosméticos; Control de calidad; Vigilancia sanitaria; Recall; Retirada.

\section{Introduction}

Personal care products such as cosmetics and perfumes are considered essential items in daily life, and are defined as preparations aimed at external use which target cleaning, perfuming, or aesthetics improvement (Brasil, 2015). The wide use and ease of access of these products are directly related to their safety and efficacy in improving the quality of life of the users. Concerning the commercialization of cosmetic products in Brazil, data from the Brazilian Association of Personal Hygiene, Perfumery and Cosmetics Industry (Abihpec, 2019) showcased that the cosmetics industry in Brazil grew an average of $6.2 \%$ in 2018. Notwithstanding, the Brazilian cosmetics market occupies the fourth position worldwide, with sales totaling more than U\$ 30 billion in 2018. By itself, Brazilian market of cosmetics corresponds to about $49 \%$ of the whole Latin American market share (Abihpec, 2019).

Nonetheless, the cosmetic industry thrived even upon the advent of commercial and politic instabilities, as in 2018 , the number of companies registered at the Brazilian National Health Surveillance Agency (Anvisa) was of 2,794. Moreover, the cosmetics sector also yielded in this single year more than 125 thousand jobs and 7,400 new products (Abihpec, 2019); thereby evidencing the size of this market and confirming the upmost importance of adequate and efficient regulatory surveillance. When taking into account the issuing of safety and efficacy standards, Anvisa has been enforcing strict guidelines for decades in order to promote the assurance of the quality and regularization of cosmetic products nationwide (Brasil, 1999).

Over the years, many resolutions have been issued and modified by Anvisa in order to meet the needs of the Brazilian market and international standards (Garbossa \& Campos, 2016). Among them, is the RDC $\mathrm{n}^{\mathrm{o}} 7$ (Brasil, 2015), which deals with regulatory issues in relation to cosmetics and lay the groundwork for the commercialization of any product. In this resolution, cosmetics are broken down into two large groups, according to the likelihood of causing unwanted events. These groups are: Grade 1 products, which are those with more basic properties, and for that reason, do not require registration but only a notification; and Grade 2 products, whose characteristics require proof of safety and efficacy, and thus, prior registration 
and authorization is needed for manufacturing and commercialization (Brasil, 2015).

Failures resulting from non-compliance with registration and quality in terms of safety and efficacy are commonly found and duly penalized. This entire process is registered and made available by Anvisa on its website in the section: "irregular products" (Brasil, 2020a). Nevertheless, the adulteration, falsification and compliance failures in regards to the production and commercialization of cosmetics occur very often, and their statistics are seldomly reported elsewhere. Therefore, this work aims to investigate data related to the inspection of cosmetics by Anvisa; thereby summarizing, analyzing, and discussing the information regarding the withdrawal of irregular products from Brazilian market between 2009 and 2020.

\section{Methodology}

Following an experimental design previously structured by our research group (Pinto, Resende \& Couto, 2021), we carried out a descriptive study divided into four stages: 1) search for information; 2) data collection; 3) organization and analysis of the collected material; 4) discussion and presentation of results. Information on irregular cosmetics was obtained, free of charge, from the Anvisa website (Brasil, 2020a), and for that, some steps were followed and are discussed in detail as it follows.

On Anvisa home page, in the "Atuação" field, the item "Fiscalização e Monitoramento" was selected, and then "Consultas e Serviços" and the sub-item "Produtos Irregulares" were accessed. All inspection actions (seizure and destruction, collection, interdiction, suspension, prohibition and alterations) of falsified and irregular cosmetics notified between January $1^{\text {st }}, 2009$, the year in which the records started to be effectively fed, to December $31^{\text {th }}, 2020$ were selected and included in the research. The terms: food; sanitizing agents; medicines; active pharmaceutical ingredients; and health products on the website were excluded from the research.

The data considered in each of the notifications were: number of the specific resolution; publication date; product; lot; company; inspection and motivation action. This information was used to compose an electronic spreadsheet, in which they were organized and double checked. The variables company, motivation, product and inspection action were analyzed as follows:

I) Companies: at first, we sought to determine the total number of notified, identified and unknown companies, in addition to the frequency of recurrences during the 12 years included in this study. Then, these companies were counted according to the region and state of origin.

II) Motivation: the total number of putative reasons were accounted and discussed considering the main points that led to irregularities.

III) Product: the information available on the Anvisa website regarding the name and possible use of the cosmetic product was considered for identification. Therefore, it was possible to group and account both those identified and those described as "all products".

IV) Inspection Actions: the total number of inspection actions was counted, then this number was compared to the total number of notifications to show which ones were most commonly used in the analyzed period.

For a better exposure, analysis and discussion of the collected data, the information was described in the form of absolute and relative frequency (\%), and presented in tables, pie and bars charts. These results were debated based on studies of the literature and national resolutions. The methodological path of this research was supported by the National Law on Access to Information - Law No 12,527 (Brasil, 2011) and by Resolution № 510 of the National Health Council (Brasil, 2016).

Furthermore, in order to correlate the observed inspection action data from Anvisa in a multifactorial analysis while shrinking dimensions for better visualization, we therefore employed Principal Components Analysis (PCA). In this work, PCA was expressed as biplot of loadings and scores containing the scatter of observational labels and eigenvectors. Moreover, 
the correlation matrix was also expressed in a table for numeric comparisons. All statistical analysis was conducted considering a confidence interval of $95 \%$ and $\mathrm{p}<0.05$.

\section{Results and Discussion}

\section{Notified companies}

The analysis of all obtained data resulted in a number of 872 notifications between the years of 2009 and 2020. Figure 1 shows the absolute frequency of occurrences in each year during that follow up. Considering that each notification can contain more than one company, Table 1 shows the total number accounted for, identified or not identified in Anvisa's inspection records.

Figure 1. Absolute frequency of annual occurrences of irregular cosmetics withdrawal from Brazilian market as recorded by the National Health Surveillance Agency (Anvisa) between 2009 and 2020.

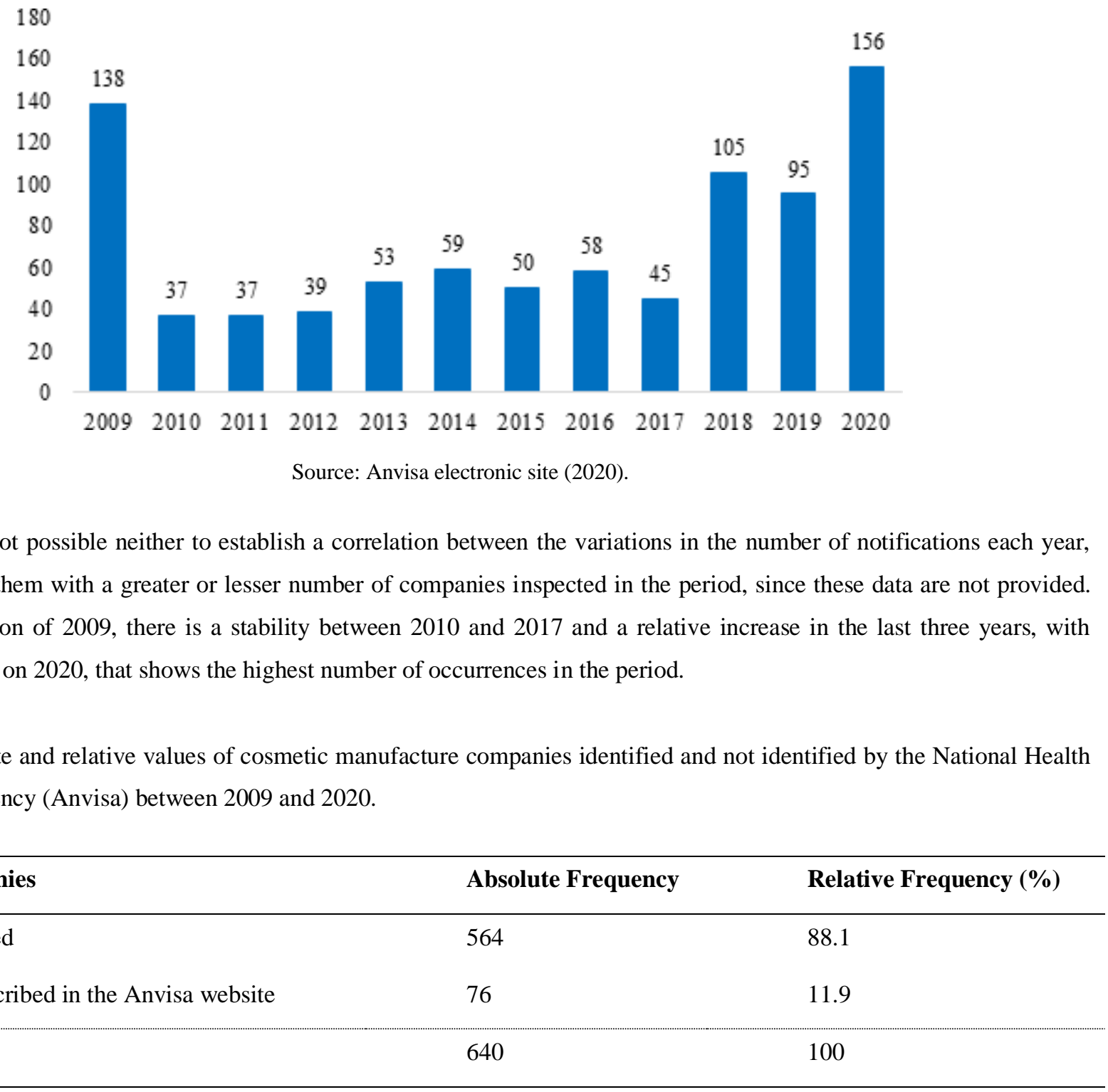

It was not possible neither to establish a correlation between the variations in the number of notifications each year, nor to associate them with a greater or lesser number of companies inspected in the period, since these data are not provided. With the exception of 2009, there is a stability between 2010 and 2017 and a relative increase in the last three years, with special emphasis on 2020, that shows the highest number of occurrences in the period.

Table 1. Absolute and relative values of cosmetic manufacture companies identified and not identified by the National Health Surveillance Agency (Anvisa) between 2009 and 2020.

\begin{tabular}{lll}
\hline Companies & Absolute Frequency & Relative Frequency (\%) \\
\hline Identified & 564 & 88.1 \\
Not described in the Anvisa website & 76 & 11.9 \\
\hline Total & 640 & 100 \\
\hline
\end{tabular}

Source: Anvisa electronic site (2020).

The high identification rate, close to $90 \%$, demonstrates the efficiency in collecting information during inspections and transparency in Anvisa's data. The result also indicates a high traceability, in other words; regardless of the inspection 
action suffered by a company, a large part could be identified and consequently held responsible for any irregularities found in the documentation. The non-identification of part of these companies is related to counterfeits, where the packaging has invalid information or companies that do not recognize the manufacture of the product. Allied to this, the lack of Business Operating Authorization (BOA) may represent another hindrance in this identification. Regarding recidivism, 119 (21.1\%) different companies had more than one irregularity notification, and together they account for $40 \%$ of all records over the period. These data show a high frequency of recurrences and expose weaknesses in the quality systems of these companies.

Figure 2. Relative frequency of companies with irregular cosmetics notified by the National Health Surveillance Agency between 2009 and 2020 depending on the region of Brazil.

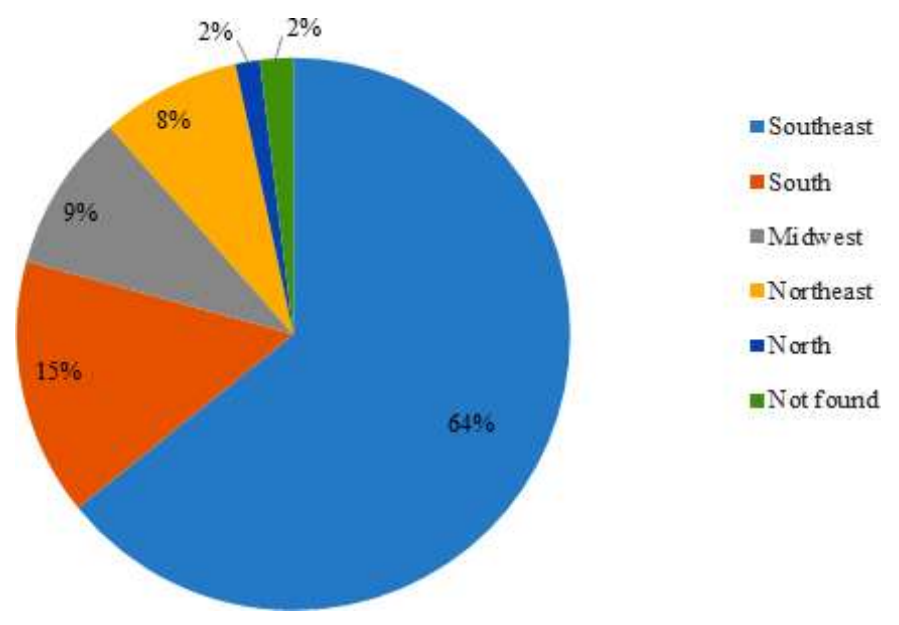

Source: Anvisa electronic site (2020).

Regarding traceability, most companies identified by Anvisa could be located, though 11 were not found either due to lack of data or location abroad. Figure 2 shows the relative frequency of the contribution of each region regarding the notified companies. The result that $64 \%$ of the companies are gathered only in the Southeast is not a remarkable finding, since this region is acknowledged by the massive presence of pharmaceuticals and cosmetics companies (Costa et. al., 2014), which invariably leads to a greater number of occurrences. On the other hand, the rate of only $2 \%$ of the total number of notified companies for the North region hardly portrays the real scenario considering the large geographic extension and economic hotspots such as trade free zones. In this sense, it cannot be affirmed that there is a lower incidence of irregularities in these locations, but it would be more plausible to point to a great regional inequality in the distribution of cosmetics industries and/or health surveillance agents.

Figure 3 shows the results previously expressed with a focus on the state location of each of these companies. It can be suggested that the richest and most populous states in the country (Brasil, 2017), which concentrate a good part of the industries, have in general a much more robust inspection chain. In this sense, there is a high number of penalized companies located in the state of São Paulo, with more than double the number of the second most notified state, Minas Gerais. 
Figure 3. Relative frequency of companies with irregular cosmetics notified by the National Health Surveillance Agency between 2009 and 2020 depending on the Brazilian state.

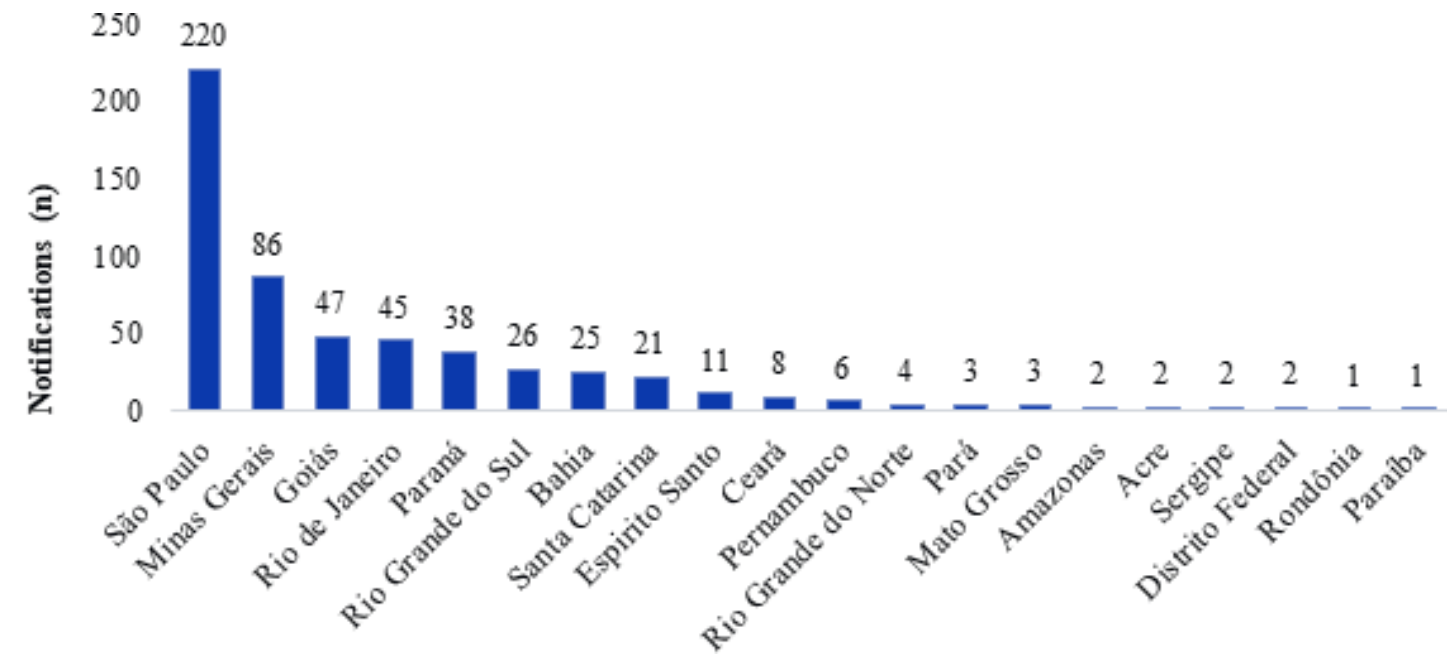

Source: Anvisa electronic site (2020).

\section{Profile of identified products}

Over the 12 analyzed years in this research, 1288 products were identified by Anvisa on its website. In addition, 92 notifications were described only as "All Products". This difference is an indication that, in the vast majority of cases, companies showed irregularities in specific products and the inspection actions were applied only to them. For a better visualization of the type of cosmetic found in this study, Table 2 was written based on an adaptation of the list of products described in the annexes of RDC $\mathrm{n}^{\circ} 7$ (Brasil, 2015), which expose Grade 1 and 2 products. The identification of products which were considered irregular was done through the name written on the notification. Although a large part has been identified, this process was hampered by the way the data is entered on the Anvisa site, as only the commercial name of the product is inputted without any additional information regarding the use and components of its formulation. Owing to this, a relatively large number of products, especially those that do not have any type of notification or registration, could not be found in the surveys. The results obtained are showcased in Table 2. 
Table 2. Absolute and relative frequency of irregular cosmetic products identified by the National Health Surveillance Agency in the period from 2009 to 2020 .

\begin{tabular}{lcc}
\hline \multicolumn{1}{c}{ Classification } & Absolute Frequency & Relative Frequency (\%) \\
\hline Hair care products (fixatives, styling creams, straighteners, dyes, tonics) & 457 & 35.6 \\
Cream, lotion, gel and oil for face and body & 182 & 14.2 \\
Shampoo and conditioner & 141 & 11.0 \\
Hand sanitizer gel & 110 & 8.6 \\
Deodorant/antiperspirant & 81 & 6.3 \\
Intimate use gels & 49 & 3.8 \\
Facial, body and intimate soap & 47 & 3.7 \\
Oral hygiene products & 33 & 2.7 \\
Disposable hygiene products & 30 & 2.6 \\
Makeup products & 27 & 2.1 \\
Sunscreen & 11 & 0.9 \\
Others* & 47 & 3.7 \\
Not identified** & 70 & 5.4 \\
\hline \multicolumn{1}{c}{ Total } & 1285 & 100 \\
\hline
\end{tabular}

* Miscellaneous products that did not reach a total of 10 recurrences (talc, repellents, enamels, among others). ** Products that could not be identified by name or through active search. Source: Anvisa electronic site (2020).

In general, it is possible to observe a strong relationship between the consumption of a particular item and the frequency of irregularities. The most recurring products that made up the item "Hair care products" were those used to model, fix or beautify hair (300) and hair straighteners (128). This high number coincides with market data. According to Abihpec, Brazil is the world's third largest consumer of hair products. It also attributes this fact to the country's ethnic diversity and wide variety of hair (Abihpec, 2013). In addition, Brazilians spend more on beauty salons than on education, on average $R \$ 20.3$ billion annually (FecomércioSP, 2015). Acknowledging this, several companies can take advantage of this high demand to place low quality products on the market.

An important data was the growth in the number of irregularities related to hand sanitizer in 2020, which are considered Grade 2 cosmetics and, therefore, subject to registration. Between the years 2009 and 2019, only 42 products had been considered irregular, and over that period, no year reached a total of 10 occurrences. By the end of 2020, however, that number reached 68 products. The considerable increase can be explained by the pandemic of the new coronavirus, the recommendation by health agencies to use $70 \%$ alcohol as a preventive measure (OPAS/OMS, 2020; Singh et. al., 2020) and its scarcity at the most critical moment of the pandemic in the country.

In this sense, once again the pattern presented in the previous case is observed, i.e., the great need of the market for a certain product and a large number of companies that take advantage of this opportunity to obtain profit in exchange for unreliable products.

\section{Main reasons for product withdrawal}

Most notifications include only a single motivation and a small part had two or three. Table 3 shows the main reasons that led cosmetics to irregularity between the years 2009 and 2020. Among the 903 reasons, the most recurrent were the lack of 
product registration, the various quality deviations and the lack of Business Operating Authorization (BOA). According to RDC No. 7 (Brasil, 2015), BOA is an indispensable item for the import and sale of any cosmetic product. Only after it, the local Health Authority will be able to verify compliance with Good Manufacturing Practices (GMP) (Brasil, 2015). The GMP tools are a set of rules that seek to guide the process of production and control of cosmetic products (Brasil, 2013a).

Therefore, the lack of BOA can be considered one of the most serious points, since its absence indicates that there is no proper monitoring by the Health Authority in its production process, as well as no evidence that this company meets quality standards in its product.

Nonetheless, it is difficult to measure the level of participation in this study in comparison to all industries countrywide, but a large number of small companies focused on the production of handcrafted or DIY (do-it-yourself) cosmetics may be included in these results, a practice that has grown with modern trends (Fonseca-Santos, Corrêa \& Chorilli, 2015; Morais, Brito \& Quintão, 2018). So far, there is no specific regulation for these products. Therefore, both small and large companies need to follow the same legislation, in other words, minimally have BOA and adapt to GMP, which includes adequate environment, equipment and activities that guarantee quality control. If, on the one hand, this is a topic that deserves greater attention from Anvisa as it distances smaller handcrafted productions from the market; on the other hand, it is understandable that these products are removed in order to ensure the safety of the population.

A considerable number of notifications were also related to specific non-compliances with RDC No. 7 (Brasil, 2015), such as notification errors, classification and change of formulas prior notice to the competent authorities. These were common practices intended to circumvent the analysis of safety and efficacy data for products that need stricter control. The motivation related to adverse events draws a lot of attention due to the small number, only 3 records in which the outcome of these events is not reported. This result is very unlikely and a direct consequence of underreporting. The National System of Notifications for Health Surveillance (NOTIVISA) was created precisely with the intention of being a tool for inspecting the post-trade of products and its use by the population and health professionals is essential, though still not frequent (Huf et al., 2013). 
Table 3. Absolute and relative frequency of motivations presented by the National Health Surveillance Agency as irregularities in cosmetic products between the years 2009 and 2020.

\begin{tabular}{lcc}
\hline Motivation & Absolut Frequency & Relative Frequency (\%) \\
\hline Lack of Registration/Notification & 319 & 35.3 \\
Quality Deviation & 234 & 25.9 \\
Company without BOA & 181 & 20.0 \\
Disagreement with RDC 7/2015 & 79 & 8.7 \\
Falsification & 34 & 3.8 \\
Non-compliance with GMP & 26 & 2.9 \\
Cancellation of Notification & 23 & 2.5 \\
Not Described & 4 & 0.4 \\
Adverse Event Notification & 3 & 0.3 \\
Total & 903 & 100 \\
\hline
\end{tabular}

Source: Anvisa electronic site (2020); BOA, Business Operating Authorization; GMP, Good Manufacturing Practices.

In a study carried out with 200 participants, $38 \%$ declared to have suffered at least one adverse reaction to cosmetic products, caused mainly by soaps, shampoos and deodorants. It also estimates that only $1.5 \%$ of the interviewees had heard of NOTIVISA, despite never having used it (Huf et al., 2013). This is the result of an underpublicized, complex and old system that needs to be taken into account by both customers and healthcare professionals, as it is the only way to start an investigation that will lead to the withdrawal of products that cause adverse events. Moreover, it is necessary to emphasize the role of the pharmacist to promote change and awareness of the population, since this professional is highly trained in aspects of drug safety and efficacy, and is present in all stages of the market chain, whether in production or inspection. Therefore, it is their job to be a reliable source of information, to always be aware of the population's complaints and to know how to act when identifying irregularities.

Non-compliance with GMP also represents a significant error, which leads to the interdiction and withdrawal of all products, since the company may have generalized failures in quality assurance (Brasil, 1977). This item, as well as the reasons for the cancellation of product notification represented some limitations in this part of the study, as Anvisa does not expose the points that caused the breach of the GMP and the cancellation. To all extent, this data that would be essential for a better assessment of these failures. On the other hand, the large number of quality deviations provided a more detailed analysis, whose results are showcased in Table 4, wherein deviations from quality in a cosmetic product are associated to potential risks to the consumer.

Nonetheless, there are laws to define parameters to be followed in order to standardize quality and minimize errors, however, the main problem came from the labels of cosmetic products. The RDC $\mathrm{n}^{\circ} 7$ (Brasil, 2015) is also responsible for assigning requirements for the labeling of cosmetics, which must contain the registration number, production code, validity, technical responsibility, instructions of use, among others. Anvisa's website does not specify which item on the label led to the irregularity, so it was not possible to establish a central cause of error.

Deviations related to physical-chemical analysis were considerably frequent, and even higher than those of labeling if considered all data $(49.8 \%$ of the total considering content, $\mathrm{pH}$ and aspect). The number of irregularities related to the 
formaldehyde content exposes a worrying panorama. The use of formaldehyde in hair straightening products is permitted with the preservative function of the formulation in concentrations of up to $0.2 \%$ (Brasil, 2013b). Precisely due to health risks, its sale and exposure has been prohibited in markets and pharmacies since 2009 (Brasil, 2009). Although, several other products with a smoothing function are allowed by Anvisa (Brasil, 2020b) such as thioglycolic acid, sodium hydroxide and calcium hydroxide, beauty salons still use formaldehyde-containing products quite often, and in an unadvised manner.

Table 4. Absolute and relative frequency of the main types of quality deviations presented in irregular cosmetics between the years 2009 and 2020 according to the National Health Surveillance Agency (Anvisa).

\begin{tabular}{|c|c|c|c|c|}
\hline \multicolumn{3}{|c|}{ Quality Deviations } & \multirow{2}{*}{$\begin{array}{c}\text { Absolut Frequency } \\
111\end{array}$} & \multirow{2}{*}{$\begin{array}{c}\text { Relative Frequency (\%) } \\
32.8\end{array}$} \\
\hline Label & & & & \\
\hline \multirow{8}{*}{ Content } & formaldehyde & 42 & \multirow{8}{*}{98} & \multirow{8}{*}{29.0} \\
\hline & ethyl alcohol & 32 & & \\
\hline & hydrogen peroxide & 6 & & \\
\hline & ammonia & 4 & & \\
\hline & thioglycolic acid & 3 & & \\
\hline & calcium hydroxide & 3 & & \\
\hline & anionic surfactant & 3 & & \\
\hline & others & 5 & & \\
\hline \multicolumn{3}{|l|}{$\mathrm{pH}$} & 59 & 17.5 \\
\hline \multicolumn{3}{|c|}{ Total Mesophilic Count } & 28 & 8.3 \\
\hline \multicolumn{3}{|c|}{ Not Specified } & 13 & 3.9 \\
\hline \multicolumn{3}{|l|}{ Aspect } & 11 & 3.3 \\
\hline \multicolumn{3}{|c|}{ Microbial contamination } & 9 & 2.7 \\
\hline \multicolumn{3}{|c|}{ Total Coliforms } & 5 & 1.5 \\
\hline \multicolumn{3}{|c|}{ Primary Skin Irritation } & 2 & 0.6 \\
\hline \multicolumn{3}{|c|}{ Lead Identification } & 2 & 0.6 \\
\hline \multicolumn{3}{|l|}{ Total } & 338 & 100 \\
\hline
\end{tabular}

Source: Anvisa electronic site (2020).

A study by Pexe (2018) sought to evaluate the exposure of beauty salon professionals to formaldehyde. The result found was higher than allowed in 39\% of these salons, in addition, when analyzing 23 samples of different products, all exceeded the established limits by Anvisa (Brasil, 2020b). Moreover, in $0.2 \%$ of the investigated products, the formaldehyde concentrations ranged from 3 to $11 \%$ (Pexe, 2018). Although a large number of procedures are performed daily in these establishments, the record of diseases in these professionals is low, which does not mean that they do not occur, but rather, they again demonstrate the lack of notification.

In addition to known acute toxicity symptoms such as irritation, shortness of breath and headache, formaldehyde is considered a carcinogenic agent, and its exposure is related to an increase in genetic damage and the incidence of leukemias (Costa et. al., 2019). In this sense, seeking to make the population aware of the dangers of products with formaldehyde in its 
composition, Anvisa has on its website a page especially dedicated to questions about haircare products (Brasil, 2020b). However, it needs to be more publicized and promoted.

The quantification of heavy metals in cosmetics has been a major concern for the academic community. Over the years, several methodologies have been developed seeking to identify and quantify lead, mainly in lipsticks (Bocca et. al., 2014), such as X-ray fluorescence spectrometry (Da Silva, David \& Pejović-Milić, 2015), laser-induced damage spectroscopy (Liu et. al., 2020) and graphite furnace atomic absorption spectrometry (Barros, Silva \& Neto, 2015).

Daily exposure to lead, which accumulates in the body, can range from anemias to neurological disorders. In this context, the National Institute of Metrology, Quality and Technology (Inmetro) in partnership with Anvisa, evaluated 15 lipstick brands, of different colors, types and prices, sold in the country. All products were presented in compliance with current legislation, with values well below the permitted $20 \mathrm{mg} / \mathrm{kg}$ (Brasil, 2012; Brasil, 2017). The results obtained corroborate to the collected data, which indicate only two irregularities related to the identification of lead between 2009 and 2020.

\section{Inspection actions}

The inspection action applied to the company is directly related to the seriousness of the irregularity presented in the motivation and is based on Law 6,437, which determines sanctions to be applied (Brasil, 1977). The notifications found in this study presented, on average, 4 inspection actions. The terms used in the composition of the table are repeated and are constantly used. Thus, it was decided not to count a total, but to ascertain in how many of the 872 notifications certain terms appear. The absolute and relative data of applied actions are shown in Table 5.

The terms "Suspension of Distribution", "Suspension of Use" and "Suspension of Manufacturing" were the most commonly used in the notifications. This is probably because, unlike the others, they have been used since 2009, while others such as "withdrawal" have only been used since 2016. It is difficult to define exactly the reasons for this, but they are probably the result of reformulations of inspection guides. All the cautionary interdiction occurred in product notifications with some type of quality deviation. In these cases, the product's commercialization is prevented until tests and analysis can prove or not its irregularity ${ }^{15}$. The revocation or annulment of the Specific Resolution was mentioned in 30 of the total notifications. A considerably low number that indicates that, once considered irregular, only in $3.4 \%$ of the cases the company is able to reverse the decision and regularize its situation. 
Table 5. Absolute and relative frequency of inspection actions applied by the National Health Surveillance Agency (Anvisa) to cosmetic products manufacturers between 2009 and 2020.

\begin{tabular}{lcc}
\hline Inspection Action & Absolut Frequency & Relative Frequency (\%) * \\
\hline Suspension of Distribution & 712 & 81.7 \\
Suspension of Use & 700 & 80.3 \\
Manufacturing Suspension & 551 & 63.2 \\
Marketing Suspension & 471 & 54.0 \\
Suspension of Disclosure & 387 & 44.4 \\
Seizure and Disposal & 317 & 36.4 \\
Retreat & 261 & 29.9 \\
Cautionary Interdiction & 95 & 10.9 \\
Storage Suspension & 46 & 5.3 \\
Revocation/Annulment of the SR & 30 & 3.4 \\
Suspension of Import & 22 & 2.5 \\
\hline
\end{tabular}

* Frequency based on total notifications in the analyzed period (872). Source: Anvisa electronic site (2020); SR: Specific Resolution.

In a recent article of our group (Pinto, Resende \& Couto 2021), data related to the withdrawal of irregular active pharmaceutical ingredients between the years 2011 and 2019 were descriptively evaluated. The analysis showed a total of 11 revocations, a high number if taking into account the 77 notifications in the period. This is an indication that companies in the pharmaceutical sector are more structured and capable of correcting their flaws. Nevertheless, more work in this direction in other areas would be ideal to establish an overview of Brazilian industry. Another interesting fact is related to the low number of irregularities in imported products (2.5\%). It would be expected that this number would be greater, considering the large flow of products that enter the country without the regularization by Anvisa.

In general, consulting the Anvisa website allowed the collection of a large amount of data to carry out this study. However, it is noted the presence of some gaps in points analyzed and discussed here, which is mainly due to the scarcity of details therein provided. Another point to be taken into account is the difficulty of accessing and obtaining this information, since there is no type of disclosure or encouragement for this search by society. Thus, these limitations must be considered in the search for future improvements in this information system.

As showcased in Table 6 and Figure 4, the first two PCs explained about $81 \%$ of the inspection data while the observational labels showcased light clustering. Moreover, the eigenvectors of the inspection actions (which were hereby inputted as attributes/independent variables) showcased convergence and were better explained by the first PC. It could be noticed that the years 2009 and 2020 are apart from the data, what is corroborated by Figure 1 due to the number of notified irregularities in these years. 
Research, Society and Development, v. 10, n. 4, e41310414337, 2021

(CC BY 4.0) | ISSN 2525-3409 | DOI: http://dx.doi.org/10.33448/rsd-v10i4.14337

Table 6. Correlation matrix of the inspection data, the same data was used in the PCA dimensional shrinkage.

\begin{tabular}{|c|c|c|c|c|c|c|c|c|c|c|c|}
\hline & Distribution & Use & Manufacturing & Marketing & Disclosure & Seizure & Retreat & Interdiction & Storage & Revocation & Import \\
\hline Distribution & 1 & 0.99806 & 0.98658 & 0.67147 & 0.66725 & 0.57016 & 0.70791 & 0.17606 & 0.51494 & 0.62304 & 0.65363 \\
\hline Use & 0.99806 & 1 & 0.98503 & 0.6531 & 0.65545 & 0.5726 & 0.69387 & 0.18376 & 0.46444 & 0.62132 & 0.61683 \\
\hline Marketing & 0.67147 & 0.6531 & 0.60604 & 1 & 0.96109 & 0.01148 & 0.96017 & -0.11695 & 0.6528 & 0.89316 & 0.61329 \\
\hline Disclosure & 0.66725 & 0.65545 & 0.61808 & 0.96109 & 1 & -0.00991 & 0.93919 & 0.01658 & 0.59561 & 0.86142 & 0.5583 \\
\hline Retreat & 0.70791 & 0.69387 & 0.65846 & 0.96017 & 0.93919 & -0.08111 & 1 & -0.18893 & 0.62693 & 0.9099 & 0.62852 \\
\hline Interdiction & 0.17606 & 0.18376 & 0.22656 & -0.11695 & 0.01658 & 0.60164 & -0.18893 & 1 & 0.06628 & -0.26029 & -0.16616 \\
\hline Storage & 0.51494 & 0.46444 & 0.51219 & 0.6528 & 0.59561 & 0.16207 & 0.62693 & 0.06628 & 1 & 0.34489 & 0.79652 \\
\hline Revocation & 0.62304 & 0.62132 & 0.55007 & 0.89316 & 0.86142 & -0.10447 & 0.9099 & -0.26029 & 0.34489 & 1 & 0.45523 \\
\hline Import & 0.65363 & 0.61683 & 0.60162 & 0.61329 & 0.5583 & 0.14244 & 0.62852 & -0.16616 & 0.79652 & 0.45523 & 1 \\
\hline
\end{tabular}

Source: Authors. 
Figure 4. Biplot of the first two PCs of the inspection data gathered from Anvisa website. Data regarding year was used as observational label while each inspection action was inputted as attribute. The amount of variance explained by each PC is depicted in each axis label.

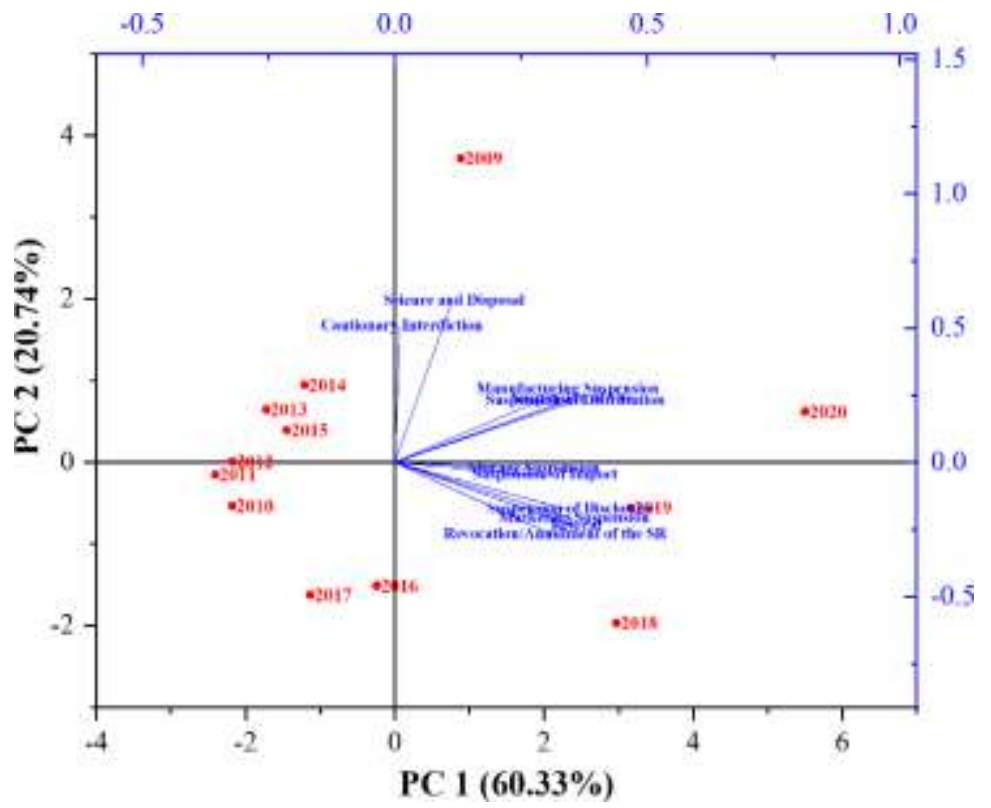

Source: Authors.

Moreover, the years: 2010; 2011;2012; 2013; 2014 and 2016 showcased clustering, what therefore suggests that these years had similar data dispersion regarding non-compliance notification, what is nonetheless in agreement with the observational statistics herein reported at Figure 1. On the other hand, aside from the inspection actions: "Seizure and Disposal" and "Cautionary Interdiction", all other attributes showcased convergent eigenvector distribution. This suggests that the inspection actions represented by these vectors may showcase proportionality in regards to their occurrence over the years of the timespan which was investigated in this study.

Furthermore, it can be suggested that the atypical increases of non-conformity in 2020 in comparison to the timespan of 2010-2016 are mainly impacted by: "Suspension of Distribution"; "Suspension of Use”; "Manufacturing Suspension"; "Marketing Suspension"; "Suspension of Disclosure"; "Retreat"; "Cautionary Interdiction"; "Storage Suspension"; "Revocation/Annulment of the SR"; and "Suspension of Import". However, the differentiation between the increase of nonconformity reporting at Anvisa website between 2020 and 2009 may be attributed to the aforementioned inspection actions and also by "Seizure and Disposal" and "Cautionary Interdiction". This differentiation may be due to the sanitary concerns brought by the ongoing coronavirus pandemic, which reached the peak of its first wave in 2020 in Brazil as preview elsewhere (Tang et. al., 2020; Serdam et. al., 2020).

The role of Anvisa in Brazilian health surveillance comprises a variety of practices and objects that become a complex face of public health. Sanitary surveillance is responsible for the independence and supervision of the production, distribution and sale of food, pesticides, cosmetics, medicines, sanitizing agents, health services, diagnostic means, equipment, authorization to operate companies, compulsory license, product registration, inspection, inspection of adverse effects, control of advertising, labels, package inserts and packaging (Silva, Costa \& Lucchese, 2018).

As part of the Brazilian healthy system, Anvisa acts in compliance with the principle of integrality that prioritizes the collective interest to the detriment of the individual, acting with a focus on quality of life and health for the population (O'Dwyer, Reis \& Silva, 2010). Therefore, through the standardization and surveillance conducted at Anvisa, the use of 
cosmetics may become more and more safe in Brazil.

\section{Conclusion}

The exposure of this large amount of analyzed data, available free of charge on the Anvisa electronic site, shows its transparency towards the public. Furthermore, it shows that the agency has done, through resolutions, guidelines and through inspections, an excellent job in withdrawing several potentially harmful products from the Brazilian market. Due to the work's findings and the large number of irregularities related to the lack of product registration and BOA, is emphasized the importance of the population being aware to the safe use of cosmetics, to seek them only from reliable companies, and by also reporting any adverse effects. In view of the explored area of this study, it is expected that it will contribute to future publications and serve as a starting point for more in-depth analysis of each of the variables herein considered. In addition, this study aims to serve as a reliable and accessible source of data, thereby raising awareness about the rational use of cosmetic products.

\section{Acknowledgments}

To the Universidade Federal of São João del-Rei for the technical support provided for carrying out this study. This study was also financed in part by the Coordenação de Aperfeiçoamento de Pessoal de Nível Superior - Brazil (CAPES) Finance Code 001.

\section{Conflicts of interest}

On behalf of the authors of the paper, I certify that we have NO affiliations with or involvement in any organization or entity with any financial interest (such as honoraria; educational grants; participation in speakers' bureaus; membership, employment, consultancies, stock ownership, or other equity interest; and expert testimony or patent-licensing arrangements), or non-financial interest (such as personal or professional relationships, affiliations, knowledge or beliefs) in the subject matter or materials discussed in this manuscript.

\section{References}

Associação Brasileira da Indústria de Higiene Pessoal, Perfumaria e Cosméticos - Abihpec. (2019). Panorama do Setor 2019. Associação Brasileira da Indústria de Higiene Pessoal, Perfumaria e Cosméticos; http://abihpec.org.br/publicacao/panorama-do-setor-2019-2/

Associação de Promoção da Produção Orgânica e Sustentável - Organis. (2020). Qual o tamanho do mercado de orgânicos no Brasil? Curitiba: Associação de Promoção da Produção Orgânica e Sustentável; https://organis.org.br/pensando_organico/qual-o-tamanho-do-mercado-de-organicos-no-brasil/.

Barros, A. I., Silva, T. V., \& Neto, J. A. G. (2015). Determination of Lead in Eye Shadow and Blush by High-Resolution Continuum Source Graphite Furnace Atomic Absorption Spectrometry Employing Direct Solid Sampling. J Braz Chem Soc.; 26(1), 140-146. http://dx.doi.org/10.5935/0103-5053.20140228.

Bocca, B., Pino, A., Alimonti, A., \& Forte, G. (2014). Toxic metals contained in cosmetics: A status report. Reg Tox and Pharm.; 68, 447-467. http://dx.doi.org/10.1016/j.yrtph.2014.02.003

Costa, J. C. S., Pagotto, M. C., Casas, C. N. P. R., Vargas, M. A., Barros, J. C., \& Bermudez, J. A. Z. (2014). Avaliação do setor produtivo farmacoquímico no Brasil: capacitação tecnológica e produtiva. Rev Eletron Comum Inf Inov Saude; 8(4), 443-460. https://doi.org/10.3395/reciis.v8i4.432

Costa, S., Costa, C., Madureira, J., Valdiglesias, V., Teixeira-Gomes, A., Pinho, P. G., Laffon, B., \& Teixeira, J. P. (2019). Occupational exposure to formaldehyde and early biomarkers of cancer risk, immunotoxicity and susceptibility. Environ Res.; 179, 108740. https://pubmed.ncbi.nlm.nih.gov/31563789/

Da Silva, E., David, A. M., \& Pejović-Milić, A. (2015). The quantification of total lead in lipstick specimens by total reflection X-ray fluorescence spectrometry. X-Ray Spectrom.; 44(6), 451-457. https://doi.org/10.1002/xrs.2629

Federação do Comércio de Bens, Serviços e Turismo do Estado de São Paulo - FecomércioSP - FecomércioSP. (2015). Brasileiros gastam mais de R\$ 20 bilhões por ano em salões de beleza; https://www.fecomercio.com.br/noticia/brasileiros-gastam-mais-de-r-20-bilhoes-por-ano-em-saloes-de-beleza 
Fonseca-Santos, B., Corrêa, M. A., \& Chorilli, M. (2015). Sustainability, natural and organic cosmetics: consumer, products, efficacy, toxicological and regulatory considerations. Braz J Pharm Sci; 51(1), 17-26. https://doi.org/10.1590/S1984-82502015000100002

Garbossa, W. A. C., \& Campos, P. M. B. G. M. (2016). Evaluation of the Brazilian Cosmetic Legislation and its impact on the industries during the 20th century. Braz J Pharm Sci; 52(2), 319-328. https://doi.org/10.1590/S1984-82502016000200010

Huf, G., Rito, P. N., Presgrave, R. F., \& Bôas, M. H. S. V. (2013). Reações adversas aos produtos cosméticos e o Sistema de Notificação em Vigilância Sanitária: um inquérito. Rev Bras Epidemiol; 16(4), 1017-1020. https://doi.org/10.1590/S1415-790X2013000400021

Instituto Brasileiro de Geografia e Estatística - IBGE. Produto Interno Bruto - PIB, 2017 https://www.ibge.gov.br/explica/pib.php

Instituto Nacional de Metrologia, Qualidade e Tecnologia - Inmetro. Relatório de análise de chumbo em batons. Brasília: Instituto Nacional de Metrologia, Qualidade e Tecnologia; 2017.http://www.inmetro.gov.br/consumidor/produtos/Relatorio_de_Analise_de_Chumbo_em_Batons.pdf

Lei $\mathrm{N}^{\circ}$ 12.527, de 18 de novembro de 2011. Regula o acesso a informações previsto no inciso 33 do artigo 5 , no inciso 2 do parágrafo 3 do artigo 37 e no parágrafo 2 do artigo 216 da constituição federal; altera a lei no 8.112, de 11 de dezembro de 1990; revoga a lei no 11.111, de 5 de maio de 2005, e dispositivos da lei no 8.159 , de 8 de janeiro de 1991; e dá outras providências. Diário Oficial União. 19 nov 2011. http://www.planalto.gov.br/ccivil_03/_ato2011-2014/2011/lei//12527.htm

Lei $\mathrm{N}^{\circ}$ 6.437, de 20 de agosto de 1977. Configura infrações à legislação sanitária federal, estabelece as sanções respectivas, e dá outras providências. Diário Oficial União. http://www.planalto.gov.br/ccivil_03/leis/16437.htm

Liu, Y., Chu, Y., Hu, Z., Zhang, S., Ma, S., Khan, M. S. et al. (2020). High-sensitivity determination of trace lead and cadmium in cosmetics using laserinduced breakdown spectroscopy with ultrasound-assisted extraction. Microchem. J.; 158, 105322. https://doi.org/10.1016/j.microc.2020.105322.

Ministério da Saúde, Agência Nacional de Vigilância Sanitária - Anvisa. Resolução RDC No 36, de 17 de junho de 2009. Dispõe sobre a proibida a exposição, a venda e a entrega ao consumo de formol ou de formaldeído (solução a 37\%) em drogaria, farmácia, supermercado, armazém e empório, loja de conveniência e drugstore. Diário Oficial União. https://bvsms.saude.gov.br/bvs/saudelegis/anvisa/2009/res0036_17_06_2009.html

Ministério da Saúde, Agência Nacional de Vigilância Sanitária - Anvisa. Resolução RDC No 44, de 9 de agosto de 2012. Aprova o Regulamento Técnico Mercosul sobre "Lista de substâncias corantes permitidas para produtos de higiene pessoal, cosméticos e perfumes" e dá outras providências. Diário Oficial União. http://bvsms.saude.gov.br/bvs/saudelegis/anvisa/2012/rdc0044_09_08_2012.html

Ministério da Saúde, Agência Nacional de Vigilância Sanitária - Anvisa. Resolução RDC No 48, de 25 de outubro de 2013a. Aprova o Regulamento Técnico de Boas Práticas de Fabricação para Produtos de Higiene Pessoal, Cosméticos e Perfumes, e dá outras providências. Diário Oficial União. 26 out 2013. https://bvsms.saude.gov.br/bvs/saudelegis/anvisa/2013/rdc0048_25_10_2013.html

Ministério da Saúde, Agência Nacional de Vigilância Sanitária - Anvisa. Resolução RDC No 15, de 26 de março de 2013b. Aprova o Regulamento Técnico "Lista De Substâncias De Uso Cosmético: Acetato De Chumbo, Pirogalol, Formaldeído E Paraformaldeído" e dá outras providências. Diário Oficial União. 27 mar 2013. http://bvsms.saude.gov.br/bvs/saudelegis/anvisa/2013/rdc0015_26_03_2013.pdf

Ministério da Saúde, Agência Nacional de Vigilância Sanitária - Anvisa. Resolução RDC No 07, de 10 de fevereiro de 2015. Dispõe sobre os requisitos técnicos para a regularização de produtos de higiene pessoal, cosméticos e perfumes e dá outras providências. Diário Oficial União. 11 fev 2015.

Ministério da Saúde, Agência Nacional de Vigilância Sanitária - Anvisa. Orientação Sobre Alisantes. Brasília: Agência Nacional de Vigilância Sanitária; 2020b. https://www.gov.br/anvisa/pt-br/acessoainformacao/perguntasfrequentes/cosmeticos/alisantes

Ministério da Saúde, Lei No 9.782, de 26 de janeiro de 1999. Define o Sistema Nacional de Vigilância Sanitária, cria a Agência Nacional de Vigilância Sanitária, e dá outras providências. Diário Oficial União. 27 jan 1999. http://www.planalto.gov.br/ccivil_03/leis/19782.htm

Ministério da Saúde,Agência Nacional de Vigilância Sanitária - Anvisa. Produtos irregulares. Brasília: Agência Nacional de Vigilância Sanitária; 2020a. http://portal.anvisa.gov.br/produtos-irregulares\#/

Ministério da Saúde. Resolução № 510, de 7 de abril de 2016. Dispõe sobre as normas aplicáveis a pesquisas em ciências humanas e sociais cujos procedimentos metodológicos envolvam a utilização de dados diretamente obtidos com os participantes ou de informações identificáveis ou que possam acarretar riscos maiores do que os existentes na vida cotidiana, na forma definida nesta resolução. Diário Oficial União. 24 maio 2016. http://bvsms.saude.gov.br/bvs/saudelegis/anvisa/2015/rdc0007_10_02_2015.pdf

Morais, I. C., Brito, E. P. Z., \& Quintão, R. T. (2018). Productive Consumption Changing Market Dynamics: A Study in Brazilian DIY Cosmetics. Lat Am. Bus. Rev.; 19(3-4), 323-347. https://doi.org/10.1080/10978526.2018.1547642

O'Dwyer, G., Reis, D. C., \& Silva, L. L. (2010). Integral care, a SUS (Brazilian Unified Health System) guideline for the sanitary surveillance. Ciênc Sau Col.; 15(3), 3351-3360. https://doi.org/10.1590/S1413-81232010000900010

Organização Pan-Americana da Saúde (OPAS) / Organização Mundial da Saúde (OMS) BRASIL. (2020). Resumo Científico - Transmissão do SARS-CoV-2: implicações para as precauções de prevenção de infecção, https://iris.paho.org/handle/10665.2/52472.

Pexe, M. E. Análise da exposição dos cabeleireiros ao formaldeído durante a realização de alisamento capilar [tese]: Universidade de São Paulo, 2018.

Pinto, N. N., Resende, K. A., \& Couto, R. O. (2021). Insumos farmacêuticos ativos irregulares no Brasil: análise descritiva de 2011 a 2019. Vig San Deb.; 9(1), 61-70. https://doi.org/10.22239/2317-269x.01456.

Serdan, T. D. A., Mais, L. N., Gorjao, R., Pithon-Curi, T. C., Curi, R., \& Hirabara, S. M. (2020). COVID-19 in Brazil: Historical cases, disease milestones, and estimated outbreak peak. Trav Med Inf Dis.; 38, 101733. https://doi.org/10.1016/j.tmaid.2020.101733 
Research, Society and Development, v. 10, n. 4, e41310414337, 2021

(CC BY 4.0) | ISSN 2525-3409 | DOI: http://dx.doi.org/10.33448/rsd-v10i4.14337

Silva, J. A., Costa, E. A., \& Lucchese, G. (2018). SUS 30 anos: Vigilância Sanitária. Ciênc Sau Col.; 23(6), 1953-1962. https://doi.org/10.1590/141381232018236.04972018.

Singh, D., Joshi, K., Samuel, A., Patra, J., \& Mahindroo, N. (2020). Alcohol-based hand sanitizers as first line of defense against SARS-CoV-2: a review of biology, chemistry and formulations. Epi Inf.; 148(229), 1-9. https://doi.org/10.1017/S0950268820002319

Tang, Y., Serdan, T. D. A., Mais, L. N., Tang, S., Gorjao, R., \& Hirabara, S. M. (2020). Epidemiology of COVID-19 in Brazil: using a mathematical model to estimate the outbreak peak and temporal evolution. Emer Microb Inf.; 9(1), 1453-1456. https://doi.org/10.1080/22221751.2020.1785337 